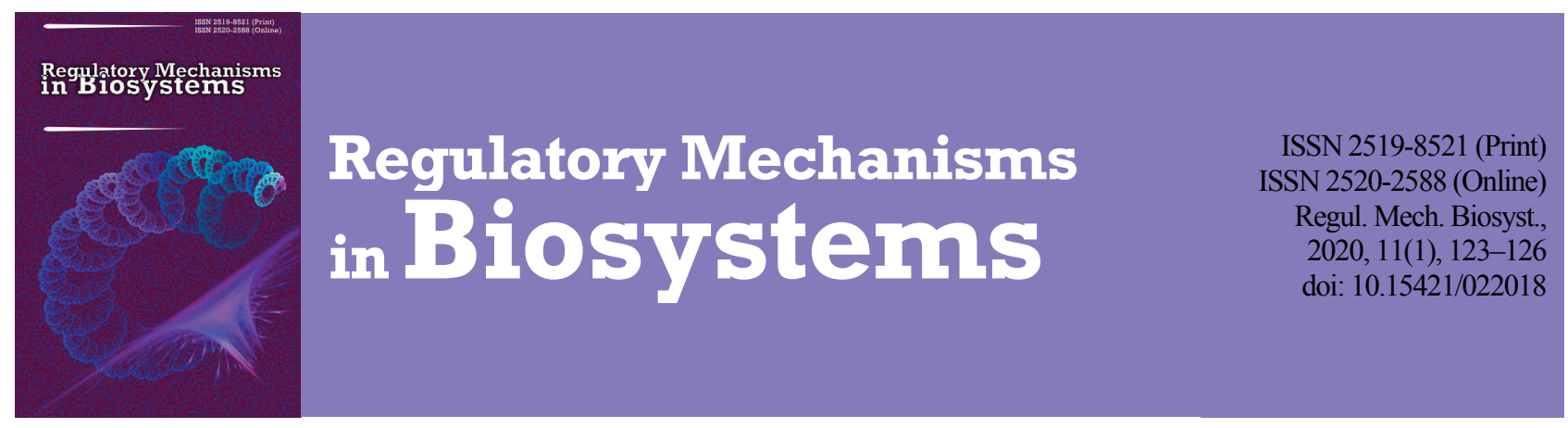

\title{
Effect of L-arginine and aminoguanidine on the cytokine profile in obstetric antiphospholipid syndrome
}

\author{
O. Z. Yaremchuk, K. A. Posokhova, P. H. Lykhatskyi, N. Y. Letniak, I. P. Moseychuk \\ I. Horbachevsky Ternopil National Medical University, Ternopil, Ukraine
}

Article info

Received 15.01.2020

Received in revised form 10.02 .2020

Accepted 13.02.2020

I. Horbachevsky Ternopil National Medical University Maidan Voli, 1, Ternopil, 46001, Ukraine.

Tel.: +38-035-225-47-84.

E-mail:

yaremchuk@tdmu.edu.ua

\begin{abstract}
Yaremchuk, O. Z., Posokhova, K. A., Lykhatskyi, P. H., Letniak, N. Y., \& Moseychuk, I. P. (2020). Effect of L-arginine and aminoguanidine on the cytokine profile in obstetric antiphospholipid syndrome. Regulatory Mechanisms in Biosystems, 11(1), 123-126. doi:10.15421/022018
\end{abstract}

Antiphospholipid syndrome (APS) is one of the autoimmune causes of miscarriage in pregnancy. We researched the influence of L-arginine $(25 \mathrm{mg} / \mathrm{kg})$, the precursor of nitric oxide synthesis, and aminoguanidine, the inhibitor of inducible NO-synthase $(10 \mathrm{mg} / \mathrm{kg})$ on the concentration of IL-1 $\beta, \mathrm{IL}-6, \mathrm{TNF}-\alpha, \mathrm{IL}-4, \mathrm{IL}-10$ in serum of BALB/c mice on the 18 th day of pregnancy in cases of APS. In the serum of the pregnant mice with APS, an increase in the concentration of proinflammatory cytokines (IL-1 $\beta$, IL-6, TNF- $\alpha$ ) and a decrease in the concentration of anti-inflammatory cytokines (IL-4 and IL-10) was evidenced, relative to those of the pregnant animals without APS. With the use of L-arginine, a decrease in the concentration of IL- $1 \beta$, IL- 6 , TNF- $\alpha$ and an increase in the concentration of IL-4 and IL-10 was established, compared with the indicators of the pregnant mice with APS. The introduction of aminoguanidine, the selective inhibitor of iNOS, did not cause any changes in IL-1 $\beta$, IL-6 and IL-10 compared with the group of animals with APS. However, a decrease in TNF- $\alpha$ concentration and an increase in IL- 4 concentration were proved in this series compared with the group of pregnant animals with APS. Combined administration of L-arginine and aminoguanidine caused a decrease in the concentration of IL-1 $\beta$, IL- 6 , TNF- $\alpha$ and an increase in the concentration of IL- 4 and IL-10, compared with the indicators of the animals with APS. Thus, the combined administration of L-arginine and aminoguanidine to the pregnant mice with APS contributes to the rebalancing of proinflammatory and anti-inflammatory cytokines in the serum more than their individual use.

Keywords: nitric oxide; interleukins; pregnancy; mice.

\section{Introduction}

According to the World Health Organization, the incidence of pregnancy miscarriage in the world is $15-25 \%$. Habitual miscarriage is a multifactorial, genetically determined disease. In $50 \%$ of cases of habitual miscarriage establishment of its cause is not possible. About $80 \%$ of unexplained reproductive losses are due to immunological disorders (Shchuruk, 2018). Antiphospholipid syndrome (APS) is one of the autoimmune causes of pregnancy miscarriage. The pathogenetic mechanisms of pregnancy loss mediated by antiphospholipid antibodies (aPL) are thrombosis, placental dysfunction and local inflammation (Chighizola \& Jesus, 2014). According to current ideas about the pathobiochemical mechanisms of APS development, its clinical manifestations during pregnancy can be realized not only through thrombus formation. Adding of aPL to the surface of endothelial cells inhibits endothelial synthesis of anti-inflammatory cytokines and nitric oxide (NO) besides activation of blood clotting factors (Ames et al., 2010; Ventskivska et al., 2011; Gomez-Puerta \& Cervera, 2014).

A normal course of pregnancy is determined by the ratio of immunomodulatory and immunosuppressive effects in the mother's body, in which regulatory proteins are directly involved - the components of the cytokine system, which during the gestational period perform regulatory function through various mechanisms aimed at preservation and development of pregnancy. Despite the fact that pregnancy is mainly characterized by anti-inflammatory immunological tolerance, the signs of inflammatory process are evidenced during various phases of pregnancy, i.e. implantation, placentation and preparation for birthing (Brann et al., 2019). The cytokine system comprises a number of proteins or glycoproteins, which are produced mainly by activated lymphocytes and the monocyte-macrophage system; to a lesser extent by fibroblasts, endothelial, somatic cells, in particular of endometrium and trophoblast. It is significant for regulation of intercellular interactions in the endometrium, implementation of endocrine effects, and determines the process of trophoblast invasion (Shchuruk, 2018). The major immune cells responsible for cytokine production are $\mathrm{CD}^{+}$. Interferon-gamma (INF- $\gamma$ ), interleukin-2 (IL-2), and tumour necrosis factor (TNF) are formed in the Th1 cells and are major effectors of cell-mediated immune response. Humoral immunity, or antibody-mediated response, is provided by IL4, IL-5, IL-6, and IL-10, which are the main effector cells synthesized by Th2. Another class of cytokines involved in the inflammatory response includes proinflammatory cytokines such as IL-1, TNF- $\alpha$ and IL-6 produced by macrophages (Aljameil et al., 2018).

In APS, violations are detected in both the Th1 link and the Th2 link. In the pathogenesis of APS, activation of proinflammatory cytokines is the most significant, primarily of TNF- $\alpha$, IL- 6 , IL- 1 , which cause development of a systemic response to inflammation (Bicadze et al., 2015). It is established that in physiological pregnancy the Th2-cell response dominates, whereas increased proinflammatory cytokine production is associated with development of pregnancy miscarriage and gestosis (Brann et al., 2019). APS is one of the causes of perinatal mortality associated with pathological conditions such as preterm birth, gestosis (Makatsariia et al., 2012; Bicadze et al., 2015). In women at risk of spontaneous abortion, activation of IL-1, IL-6, TNF $\alpha$, IL-8 is observed the most frequently (Shchuruk, 2018). In the pathogenesis of APS, hemostasis system decompensation is present, which is followed by a systemic inflammatory response, development of endothelial dysfunction and DIC. These processes are a pathogenetic basis for development of multiple organ failure (Makatsariia et al., 2012; Bicadze et al., 2015). 
When aPL interacts with membrane phospholipids, an imbalance of cytokine and kinin cascade components develops, apoptosis and necrosis occur as well (Tang et al., 2019).

The nitric oxide (NO) system is one of the significant links in the mechanisms of APS development (Ames et al., 2010). As a secondary messenger, it is involved in numerous functions under physiological conditions and in cases of pathology: immune regulation, cell differentiation, tissue morphogenesis, cytotoxicity, cell death, smooth muscle relaxation, neurotransmission (Ostapchenko et al., 2010). In APS, disturbance of the synthesis and bioavailability of NO occurs (Ames et al., 2010).

Despite the number of scientific studies on pathobiochemical mechanisms of APS development in pregnancy, the issues of how the changes in the NO system activity influence the balance of proinflammatory and anti-inflammatory cytokines in this pathology have not been studied yet.

The aim of the study was to assess the effect of L-arginine and aminoguanidine on the concentration of proinflammatory (IL-1 $\beta$, IL-6, TNF$\alpha$ ) and anti-inflammatory (IL-4, IL-10) cytokines in the serum of pregnant $\mathrm{BALB} / \mathrm{c}$ mice with antiphospholipid syndrome.

\section{Materials and methods}

The studies were performed using BALB/c female mice kept on a standard vivarium diet. The work was carried out according to the principles of bioethics in accordance with the "General Ethical Principles for Animal Experiments" approved by the First National Congress on Bioethics (Kyiv, 2001), and the provisions of the "European Convention for the Conservation of Vertebrate Animals for Experimental and Other Scientific Purposes" (Strasbourg, 1986) and EU Directive 2010/10/63 EU on animal experiments.

The APS was modeled using cardiolipin (Sigma, USA), which was administered intramuscularly four times ( $30 \mu \mathrm{g}$ per 1 injection, with a 14day interval). To enhance the efficacy of immune response, cardiolipin was emulsified in $75 \mu \mathrm{L}$ of the complete Freund's adjuvant (Difco Laboratories, USA) (first injection); the subsequent injections were performed with incomplete Freund's adjuvant (Zaichenko et al., 2011). The experimental animals were divided into 5 groups: the I group (control) - the animals without APS; the II group - the animals with experimental APS; the III group - the animals with APS administered L-arginine hydrochloride (L-arginine) (Sigma, USA), $25 \mathrm{mg} / \mathrm{kg}$; the IV group - the APS animals administered aminoguanidine (Chimlaboratorreaktyv, Ukraine), $10 \mathrm{mg} / \mathrm{kg}$; the $\mathrm{V}$ group - the animals with APS administered L-arginine in combination with aminoguanidine. L-arginine and aminoguanidine were administered intraperitoneally once a day, daily for 10 days before fertilization and for 17 days of pregnancy (Posokhova et al., 2013). Animals in the control group were administered identical volumes of the solvent intraperitoneally. In 10 days after the beginning of L-arginine and aminoguanidine administration, the females of all groups were mated with males (in the ratio of 1 male per 3 females) and were taken out of the experiment on the 18th day of pregnancy under thiopental sodium anaesthesia $(50 \mathrm{mg} / \mathrm{kg}$ of animal weight). Vaginal smears have been studied to confirm pregnancy (Zaichenko et al., 2011).

The concentration of IL-1 $\beta$, IL- 6, TNF- $\alpha$, IL- 4 , IL-10 in the serum was determined by Enzyme-Linked Immunosorbent Assay (ELISA) using standard kits adapted for mice by Express Biotech International, USA (Mouse IL-1 $\beta$ ELISA Assay, Mouse IL-6 ELISA Assay, Mouse TNF- $\alpha$ ELISA Assay, Mouse IL-10 ELISA Assay, Mouse IL-4 ELISA Assay).

Analysis of the data was made using Statistica 10.0 (StatSoft Inc., USA) program. The data are presented in tables as $\mathrm{x} \pm \mathrm{SD}(\mathrm{x} \pm$ standard deviation). Differences between the values in the control and experimental groups were determined using the Tukey test, where the differences were considered reliable at $\mathrm{P}<0.05$.

\section{Results}

In the BALB/c mice with APS on the 18th day of pregnancy, an increase in concentration of IL- $1 \beta$ of 4.6 times, IL- 6 - 3.5 times, TNF- $\alpha-$ 4.8 times in the serum was evidenced, compared to the controls (the pregnant animals without APS, Table 1). At the same time, a decrease in the concentration of anti-inflammatory cytokines IL-4 - by 2.1 times and IL10 - by 1.7 times took place, compare to the control (Table 2 ).

\section{Table 1}

Serum levels of proinflammatory cytokines of pregnant BALB/c mice in antiphospholipid syndrome and in administration of L-arginine and aminoguanidine $(\mathrm{x} \pm \mathrm{SD}, \mathrm{n}=10)$

\begin{tabular}{llcl}
\hline \multicolumn{1}{c}{ Group of animals } & $\mathrm{IL}-1 \beta, \mathrm{pg} / \mathrm{mL}$ & $\mathrm{IL}-6, \mathrm{pg} / \mathrm{mL}$ & $\mathrm{TNF}-\alpha, \mathrm{pg} / \mathrm{mL}$ \\
\hline Control & $12.64 \pm 0.69$ & $9.96 \pm 0.47$ & $13.94 \pm 0.70$ \\
APS & $58.72 \pm 2.22^{*}$ & $34.97 \pm 1.63^{*}$ & $66.90 \pm 2.33^{*}$ \\
APS + L-arginine & $51.05 \pm 1.34 * *$ & $20.51 \pm 0.82^{* *}$ & $57.07 \pm 2.09^{* *}$ \\
APS + aminoguanidine & $56.36 \pm 3.00$ & $32.17 \pm 1.26$ & $37.91 \pm 2.33^{* *}$ \\
APS + L-arginine + & $44.18 \pm 1.60^{* *}$ & $22.84 \pm 0.84^{* *}$ & $31.11 \pm 1.27^{* *}$ \\
aminoguanidine & & & \\
\hline
\end{tabular}

Notes: $* \mathrm{P}<0.001$ - statistically significant differences compared to the control group; $* * \mathrm{P}<0.05-$ statistically significant differences compared to the group of animals with APS.

\section{Table 2}

Serum levels of anti-inflammatory cytokines of pregnant BALB/c mice with antiphospholipid syndrome and with administration of L-arginine and aminoguanidine $(\mathrm{x} \pm \mathrm{SD}, \mathrm{n}=10)$

\begin{tabular}{lll}
\hline \multicolumn{1}{c}{ Group of animals } & $\mathrm{IL}-4, \mathrm{pg} / \mathrm{mL}$ & $\mathrm{IL}-10, \mathrm{pg} / \mathrm{mL}$ \\
\hline Control & $77.35 \pm 5.18$ & $117.13 \pm 4.73$ \\
APS & $36.33 \pm 1.61^{*}$ & $67.37 \pm 2.05^{*}$ \\
APS + L-arginine & $46.73 \pm 2.61^{* *}$ & $79.46 \pm 2.93^{* *}$ \\
APS + aminoguanidine & $43.79 \pm 2.44^{* *}$ & $74.44 \pm 2.70$ \\
APS + L-arginine + aminoguanidine & $59.87 \pm 2.90^{* *}$ & $90.05 \pm 1.87^{* *}$ \\
\hline
\end{tabular}

Notes: see Table 1.

With the use of the precursor of NO L-arginine synthesis, a decrease in the concentration of IL- $1 \beta$ by $13 \%$, IL- 6 - by $41 \%$, TNF-a - by $15 \%$ was evidenced, relative to the control (Table 1). At the same time, the concentration of anti-inflammatory cytokines IL 4 increased by $27 \%$ and IL-10 - by 18\%, compared to the group of animals with APS (Table 2).

The administration of a selective inhibitor of the inducible nitric oxide synthase (iNOS) of aminoguanidine did not cause significant changes in the concentration of IL-1 $1 \beta$, IL- 6 and IL-10 in the blood serum, compared to the similar indicators in the animals with APS. At the same time, in this group a decrease in the concentration of TNF- $\alpha$ by $45 \%$ was evidenced, compared to the animals with APS (Table 1). It was established that aminoguanidine administration was followed by increased concentration of IL-4 by $20 \%$ (Table 2 ).

In cases of a combined use of $\mathrm{L}$-arginine and aminoguanidine, a decrease in the concentration of IL- $1 \beta$ by $25 \%$, IL- 6 - by $35 \%$, TNF-a - by $54 \%$ in the serum of BALB/c mice with APS on the 18 th day of pregnancy was established, relative to the corresponding indicators of the groups of animals with APS (Table 1). At the same time, the concentration of anti-inflammatory cytokines increased: IL- 4 - by $64 \%$ and IL- 10 - by $34 \%$ (Table 2).

\section{Discussion}

Cytokines are significant in pregnancy maintenance, and are involved in embryogenesis, the process of initiation and development of some organs, including the immune system (Sulagna \& Pallav, 2017). As a result of our studies, an increase in the concentration of proinflammatory cytokines (IL-1 $\beta$, IL- 6, TNF- $\alpha$ ) in the serum of BALB/c mice with APS on the 18th day of pregnancy was established, compared to those of the pregnant animals without APS. The attained results are consistent with the literature. Cytokine imbalance with a predominance of proinflammatory cytokines may cause impaired development of the trophoblast, which leads to the risk of pregnancy termination (Shchuruk, 2018).

The mechanism by which aPL leads to pregnancy loss in the patients with APS has not been sufficiently studied yet. Initially, this complication was thought to be associated with intra-placental thrombosis, but it is contradictory. aPL affect the implantation of the embryo into the uterus, inhibit migration of trophoblast cells and impaired expression of endometrial differentiation markers. The trophoblast expresses $\beta$-2-glycoprotein-I ( $\beta 2 \mathrm{GPI})$, which can bind to the cell surface of the tropho- 
blast. Thus, aPL can bind to $\beta 2 \mathrm{GPI}$ on the trophoblast and reveal pathogenicity. It is also established that anti- $\beta 2 \mathrm{GPI}$ antibodies in the patients with APS affect cytokine production in the trophoblast (Rahman, 2016). Antibodies against $\beta 2 \mathrm{GPI}$ activate cytokine production during the first trimester of pregnancy, which may provoke inflammation and trophoblasts' cell death (Chighizola \& Jesus, 2014). During the second immunological phase of pregnancy, the maternal body, the placenta and the foetus adapt to each other, and the anti-inflammatory immunological state prevails. A conditional concept for this anti-inflammatory condition is the transition from production of inflammatory Thl cytokines to Th2 anti-inflammatory cytokines through regulation of NK and lymphokine-activated cells. Activation of cytokines (IL-3, IL-4, IL-5, IL-10) is evidenced which minimizes activation of Th1-type cytokines. Normally, pregnancy is characterized as a Th2-dominant state. The exact mechanism by which immune factors cause miscarriage recurrence has not been defined, but may involve modulation or imbalance between different cells of the immune system (AlJameili et al., 2018).

The dominance of proinflammatory cytokines causes pathology of the placenta and the foetus development and may lead to its intrauterine death. However, they can also prevent the pathological spread of the trophoblasts, and TNF- $\alpha$ is able to protect the fetoplacental complex (Chighizola \& Jesus, 2014). aPL-induced trophoblast inflammation leads to synthesis of proinflammatory IL- $1 \beta$ and IL- 8 by activating Toll-like receptor 4 (TLR4) and its adapter protein MyD88 (Abrahams et al., 2017). Endothelial cells are both the producers and effectors of IL-1, IL-6, IL-8 and affect synthesis of these cytokines when activated. IL-1 stimulates prostaglandin production by the myometrium caduceus membrane (Shchuruk, 2018). The role of IL-6 expression during pregnancy and its prognostic significance for pregnancy outcome have not been fully studied (AlJameili et al., 2018). This interleukin is the main regulator of immune response, responses of the acute phase of inflammation and hematopoiesis, and a mediator of protective processes against infection and tissue damage. IL-6 production is stimulated by other cytokines: IL- 1 , IL-2, TNF- $\alpha$, etc., with minimal IL-6 production, which is a marker of infection during pregnancy (Shchuruk, 2018).

TNF- $\alpha$ is one of the most important markers of inflammation (AlJameili et al., 2018). The leading role of TNF- $\alpha$, as one of the major mediators of the inflammatory response in the development of obstetric complications in cases of APS, has been defined (Makatsariia et al., 2012; Bicadze et al., 2015). In the study of Aljameil et al. (2018), an increase in TNF- $\alpha$ level in the serum in women who had miscarriage was established, which is confirmed by the results presented in our research. The levels of IL-6 in the serum were high, while INF- $\gamma$ and TNF- $\alpha$ were low in the pregnant women with a normal course. APL causes a rapid increase in decidual and systemic levels of TNF- $\alpha$. aPL increase TF in neutrophils, which exacerbates the oxidative burst and thus activates mechanisms of trophoblast damage and pregnancy loss (Abrahams et al., 2017). There are various mechanisms through which TNF- $\alpha$ may cause pregnancy loss. In particular, it enhances prostaglandin synthesis leading to uterine contraction (Shchuruk, 2018). The involvement of TNF- $\alpha$ in apoptosis processes is the other mechanism. Increased TNF- $\alpha$ levels adversely affect the implantation of the embryo and reduce blood flow to the embryo, leading to vascular thrombosis. The increase in serum TNF- $\alpha$ level in cases of APS presented in the research is confirmed by the study results by Aljameil et al. (2018). These authors found out that a decrease in proinflammatory cytokines, such as TNF- $\alpha$, IL-1 $\beta$, and an increase in the concentration of anti-inflammatory cytokines, in particular IL-10, was evidenced in the healthy pregnant women.

The obtained results on the decrease in the concentration of anti-inflammatory cytokines (IL-4 and IL-10) in the serum of the BALB/c mice with APS on the 18th day of pregnancy, compared with those of the pregnant animals without APS, are consistent with the literature. According to Ventskivska et al. (2011), significantly lower concentrations of anti-inflammatory IL-4 and IL-10 were evidenced in pregnant women with APS compared to those in the patients of the control group. In pregnancy, there are a number of changes aimed at maintaining pregnancy and preventing the rejection of foetal eggs, which include enhancing the humoral immunity and production of Th2 cytokines (IL-4, IL-10) (Shchuruk, 2018). According to Ventskivska et al. (2011), in pregnancy, the anti- inflammatory cytokines are significant because of suppression of the immune system cellular component, as well as antagonism with proinflammatory cytokines regarding the connective tissue components of the cervix. Timely NO production under the influence of iNOS and formation of reactive oxygen intermediates are critical components of effective immune response (Salim et al., 2016). To date, there is insufficient information on the role of changes in NO system activity in the balance of proinflammatory and anti-inflammatory cytokines, as well as in the expression of apoptosis-involved factors in APS. Accordingly, search for effective remedies for management of disorders in pregnancy with underlying APS among the modulators of NO synthesis is an urgent matter. It is confirmed by the lack of a single approach regarding the role of the NO system in APS development.

In our research, a decrease in the concentration of proinflammatory cytokines (IL-1 $\beta$, IL-6, TNF-a) and an increase in the concentration of anti-inflammatory cytokines (IL-4, IL-10) were established under the use of the precursor of NO L arginine synthesis in the BALB/c mice with APS on the 18th day of pregnancy, compared to those in the pregnant animals with APS. The metabolism of L-arginine is carried out by oxidative conversion involving NOS to NO and L-citrulline and nonoxidative involving arginase (3.5.3.1) to urea and ornithine. Secretion of humoral anti-inflammatory cytokines IL-4, IL-10, IL 13 induces the expression of the arginase I enzyme. Arginase I regulates NO synthesis by reducing the availability of L-arginine (Shejbak \& Pavljukovec, 2013). According to the literature (Shejbak \& Pavljukovec, 2013), L-arginine decreases the level of IL-6, which is consistent with the data attained in our research. NO can induce the synthesis of the heat shock protein Hsp 70 , which protects hepatocytes from the action of TNF- $\alpha$ (Ostapchenko et al., 2010). Impairment of NO bioavailability in APS may be associated with a decrease in the concentration of substrate - L-arginine, as well as an increased formation of superoxide-anion, which quickly binds and inactivates $\mathrm{NO}$ with the formation of toxic peroxynitrite (Lopez-Pedrera et al., 2016).

It is established that IL-1 $\beta$ activates synthesis of IL- 6 and iNOS, causing increased NO synthesis (Zhang et al., 2001). The proinflammatory cytokines TNF- $\alpha$, IFN- $\gamma$, IL-2 also increase the level of iNOS (Shejbak \& Pavljukovec, 2013). We used aminoguanidine to correct the changes that occur in APS. Aminoguanidine is a nucleophilic hydrazine compound, a structural analogue of L-arginine, which is a competitive inhibitor of iNOS (Saha et al., 2010; Genes et al., 2017). The results of the research showed that introduction of aminoguanidine led to a decrease in the concentration of TNF- $\alpha$, compared to the indicators of pregnant animals with APS. It was also found that in the group of animals with APS administered aminoguanidine the concentration of IL-4 was higher than in the group of animals with APS on the 18th day of pregnancy.

According to the literature, a decrease in the synthesis and bioavailability of NO and endothelial NOS activity occurs in APS (Ames et al., 2010). On the other hand, an increase in iNOS activity was evidenced in APS (Lopez-Pedrera et al., 2016). These data prompted studying the effects of the combined use of the NO synthesis precursor and the iNOS blocker. It was established that the combined administration of L-arginine and aminoguanidine into the BALB/c mice with APS led to a decrease in the concentration of proinflammatory cytokines (IL-1 $\beta$, IL- $6, \mathrm{TNF}-\alpha$ ) and an increase in the concentration of anti-inflammatory cytokines (IL-4, IL-10) on the 18th day of pregnancy, relative to the indicators of the group of animals with APS. The results attained prove that the most effective of the three methods of correction of APS disorders is the combined use of L-arginine and aminoguanidine. This is confirmed by the fact that in the serum of BALB/c mice with APS a decrease in the concentration of proinflammatory cytokines (IL-1 $\beta$, IL- 6, TNF-a) and an increase in the concentration of anti-inflammatory cytokines (IL-4, IL10) took place on the 18th day of pregnancy, compared to the groups of animals administered L-arginine and aminoguanidine separately.

Thus, the interrelation between hepatotoxic and protective mechanisms of NO determines its role in cell damage (Kiseleva et al., 2019).

\section{Conclusions}


An increase in the concentration of IL- $1 \beta, \mathrm{IL}-6, \mathrm{TNF}-\alpha$ and a decrease in the concentration of IL- 4, IL- 10 in the serum of BALB/c mice with APS on the 18th day of pregnancy was established relative to the controls. With the use of $\mathrm{L}$ arginine, the NO synthesis precursor, a decrease in the concentration of proinflammatory cytokines and an increase in the concentration of anti-inflammatory cytokines was evidenced, compared to the indicators of the animals with APS. The introduction of aminoguanidine was accompanied by a decrease in the concentration of TNF-a and an increase in the concentration of IL-4. In the case of combined use of L-arginine and aminoguanidine, a decrease in the concentration of IL- $1 \beta$, IL- 6 , TNF-a and an increase in the concentration of IL-4, IL-10 was established in the serum of BALB/c mice with APS on the 18th day of pregnancy. Therefore, the results of the study proved that the most effective of the three methods of correction of pro-inflammatory and anti-inflammatory cytokines imbalance in APS is the combined use of L-arginine, NO synthesis precursor, and aminoguanidine, the blocker of inducible NOS.

\section{References}

Abrahams, V. M., Chamley, L. W., \& Salmon, J. E. (2017). Emerging treatment models in rheumatology: Antiphospholipid syndrome and pregnancy: $\mathrm{Pa}-$ thogenesis to translation. Arthritis Rheumatology, 69(9), 1710-1721.

Aljameil, N., Tabassum, H., AlMayouf, H, Alshenefy, A., Almohizea, M. M., \& Ali, M. N. (2018). Identification of serum cytokines as markers in women with recurrent pregnancy loss or miscarriage using MILLIPLEX analysis. Biomedical Research, 29, 3512-3517.

Ames, P. R. J., Batuca, J. R., Ciampa, A., Ccone, L. I., \& Alves, J. D. (2010). Clinical relevance of nitric oxide metabolites and nitrative stress in thrombotic primary antiphospholipid syndrome. The Journal of Rheumatology, 37(12), 2523-2530.

Bicadze, V. O., Hizroeva, D. H., Idrisova, L. J., Abramjan, R. R., Andreeva, M. D., \& Makacarija, A. D. (2015). Katastroficheskij antifosfolipidnyj sindrom [Catastrophic antiphospholipid syndrome]. Voprosy Patogeneza. Akusherstvo, Ginekologija i Reprodukcija, 2, 32-53 (in Russian).

Brann, E., Edvinsson, A., Rostedt Punga, A., Sundström-Poromaa, I., \& Skalkidou, A. (2019). Inflammatory and anti-inflammatory markers in plasma: From late pregnancy to early postpartum. Scientific Reports, 9, 1863.

Chighizola, C. B., \& Jesus, G. R. (2014). Antiphospholipid antibodies and infertility. Lupus, 23, 1232-1238.

Gomez-Puerta, J. A., \& Cervera, R. (2014). Diagnosis and classification of the antiphospholipid syndrome. Journal of Autoimmunity, 48 -49, 20-25.

Kiseleva, A. V., Churliaev, I. A., \& Grigorev, E. V. (2019). Rol' oksida azota v povrezhdenii neironov pri kriticheskikh sostoianiiakh [The role of nitric oxide in damage to neurons in critical conditions]. Obshchaia Reanimatologiia, 5, 80-84 (in Russian)

Lopez-Pedrera, C., Barbarroja, N., \& Jimenez-Gomez, Y. (2016). Oxidative stress in the pathogenesis of atherothrombosis associated with antiphospholipid syndrome and systemic lupus erythematosus: New therapeutic approaches. Rheumatology, 55, 2096-2108.

Makatsariia, A. D., Bitsadze, V. O., \& Khizroeva, D. K. (2012). Katastroficheskiy antifosfolipidnyy sindrom $\mathrm{v}$ akusherskoy praktike [Catastrophic antiphospholipid syndrome in obstetric practice]. Zhurnal Akusherstva i Zhenskikh Bolezney, 3, 7-21 (in Russian).

Ostapchenko, L. I., Synelnyk, T. B., Rybalchenko, T. V., \& Rybalchenko, V. K. (2010). Biokhimichni mekhanizmy apoptozu [Biochemical mechanisms of apoptosis]. Kyiv University, Kyiv (in Ukrainian).

Posokhova, K. A., Sampara, S. R., \& Sak, I. Y. (2013). Vplyv tivortinu na perebih vahitnosti, stan plodiv ta novonarodzhenykh pry eksperymentalnomu antyfosfolipidnomu syndromi [Effect of tivortin on pregnancy, fetal and newborn status in experimental antiphospholipid syndrome]. Medychna Khimiia, 15(4), 26-29 (in Ukrainian).

Rahman, A. (2016). Antiphospholipid syndrome in pregnancy. Indian Journal of Rheumatology, 11, 117-121.

Saha, S., Mundia, M. M., Zhang, F., Demers, R. W., Korobova, F., Svitkina, T., Perieteanu, A. A., Dawson, J. F., \& Kashina, A. (2010). Arginylation regulates intracellular actin polymer level by modulating actin properties and binding of capping and severing proteins. Molecular Biology of the Cell, 21, 1350-1361.

Salim, T., Sershen, C. L., \& May, E. E. (2016). Investigating the role of TNF- $\alpha$ and IFN- $\gamma$ activation on the dynamics of iNOS gene expression in LPS stimulated macrophages. PLoS One, 11(6), e0153289.

Shchuruk, N. V. (2018). Osoblyvosti balansu tsytokiniv u zhinok iz reproduktyvnymy vtratamy $\mathrm{v}$ anamnezi $\mathrm{v}$ dynamitsi uskladnenoji i neuskladnenoji vahitnosti [Features of cytokine balance in women with a history of reproductive loss in the dynamics of complicated and uncomplicated pregnancy]. Akusherstvo ta Hinekolohiia, 1, 132-136 (in Ukrainian).

Shejbak, V. M., \& Pavljukovec, A. J. (2013). Arginin i immunnaja sistema - vozmozhnye mehanizmy vzaimodejstvija [Arginine and the immune system are possible interaction mechanisms]. Vestnik Vitebskogo Gosudarstvennogo Medicinskogo Universiteta, 12(1), 6-13 (in Russian)

Sulagna, D., \& Pallav, S. (2017). Defining pregnancy phases with cytokine shift. Journal of Pregnancy and Reproduction, 1(4), 1-3.

Tang, K. T., Hsieh, T. Y., Chao, Y. H., Li, J. P., Lan, J. L., Lin, C. C., \& Chen, D. Y (2019). Apoptosis in patients with primary antiphospholipid antibody syndrome. International Journal of Rheumatic Diseases, 22(4), 677-685.

Ventskivska, I. B., Bila, V. A., \& Zahorodnia, O. S. (2011). Rol' prykhovanykh trombofilichnykh staniv $\mathrm{v}$ patohenezi zahrozy peredchasnykh polohiv [The role of latent thrombophilic conditions in the pathogenesis of the threat of preterm birth]. Zdorove Zhenshchyn, 58, 173-176 (in Ukrainian).

Zaichenko, H. V., Lar'ianovska, I. B., \& Deieva, T. V. (2011). Morfolohichnyi stan matky ta platsenty pry eksperymental'nomu modeliuvanni hestatsiinoho antyfosfolipidnoho syndromu na myshakh [Morphological state of the uterus and placenta in experimental modeling of gestational antiphospholipid syndrome in mice]. Ukrainskyi Medychnyi Almanakh, 14(4), 136-141 (in Ukrainian).

Zhang, G. L., Wang, Y. H., Teng, H. L., \& Lin, Z. B. (2001). Effects of aminoguanidine on nitric oxide production induced by inflammatory cytokines and endotoxin in cultured rat hepatocytes. World Journal of Gastroenterology, $7(3), 331-334$ 